\title{
THE QUESTION OF TITLE DURING THE SUBSISTENCE OF A POLICY
}

\author{
To the Editor of the Transactions of the Faculty of Actuaries,
}

SIR,-May I call the attention of the Faculty to the recent decision of the First Division of the Court of Session in the case of the Allgemeine Deutsche Credit Anstalt and other's v. The Scottish Amicable Life Assurance Society and others, reported in the Scots Law Times, vol. xiv., p. 775, and vol. xv., p. 427 .

The action was one of declarator raised by two firms of bankers in Leipzig, Germany, against the Scottish Amicable, and also against several persons who at one time or another were interested in a whole-life policy of that Society on the life of a certain Oscar Philipp. The pursuers, who desired to raise money on the policy, brought this action in the lifetime of Philipp concluding for declarator (1) that they had good and undoubted right and title to the extent of one-half each in the said policy, and that the defenders other than the Society had no right to the policy or its proceeds, and (2) that the Society was "bound, on the sums contained in the policy becoming due and payable, to make payment thereof to the pursuers, or to any person or persons who may have derived right through them in and to the policy."

The policy had been taken out in 1884 in name of a certain Gustav von Portheim, a creditor of Philipp. Since its issue it had been the subject of various transactions by way of pledge, assignation, ete., in Germany and in England, and numerous notices with reference to these transactions had been received by the Society. From these notices it appeared that questions of difficulty, including questions of foreign law, might require to be investigated before it could be determined who was in right of the policy. On being asked by the pursuers in 1904 to admit their title the Society replied that they could express no opinion as to the effect or validity of that title, until they were called upon to make payment under the policy. When the present action was brought it was defended by the Society only, certain of the other defenders making no appearance, and the others consenting to decree against them. The Soeiety pled inter alia that the action was premature and incompetent, and the Lord Ordinary (Lord Ardwall) sustained this plea and dismissed the action. His Lordship found that there was nothing in the contract of insurance entitling any person who might acquire right to the policy to come to the Society before the sums in the policy fell due and demand an acknowledgment of the validity of his title. Such an acknowledgment, he considered, would amount to little less than a guarantee of the title. What the pursuers were now seeking was really to substitute for the original contract to pay to Gustav von Portheim and his assignees a new contract to pay to the pursuers or any person who might derive right from them. He held that the pursuers were not now entitled to have their right in the policy declared, because it did not appear that all the persons who might have an interest in the policy were parties to the action, or that the persons against whom the action was brought were the proper contradictors of the declarator concluded for.

The pursuers reclaimed, and on 26th October 1907 the First Division adhered to the judgment of the Lord Ordinary. In the course of his opinion the Lord President, with whom the other members of the Court (Lords Kinnear and Dundas) agreed, said: "When the pursuers put in 
their claim against the insurance company they put in something which in my judgment they were not entitled to ask, because no one can tell whother the company will ever be bound to make payment to the pursuers. No one knows who will be the claimants when the time comes for the policy to mature, or when it has been turned into a claim by means of a surrender. Therefore to entertain a declarator $a b$ ante against the insurance company seems out of the question." His Lordship added : "I have never known, and counsel have been unable to produce to us, any action of declarator where the Court gave a declurator as to a right without there being a proper contradictor present. The insurance company is not the contradictor as in the question of whom the property belongs to. The contradictor must be found among the ranks of the parties to whom at various times the policy belonged, and depends upon the question of whether these various links of the chain of title are or are not correct. The insurance company have no interest whatever, except simply to pay the policy when it becomes a proper claim. Therefore it seems to me that the cases where declarators have been obtained have no application to the case before us."

The question raised and decided in this action is an entirely novel one so far as our Courts are concerned. In Kngland, however, a similar question was under consideration in the case of Honour v. The Equitable Life Assurance Society of the United States (L.R. 1900, 1 Ch. 852), which does not appear to have been quoted to the Court here. In that case an assignee of a policy on which the insurance company had repudiated liability on the ground of misrepresentation, and had refused to receive further premiums, brought an action against the company in the lifetime of the insured to have it declared that the policy was valid, and for an injunction to restrain the company from repudiating it. On the company undertaking that if an action was afterwards brought on the policy they would not rely as a defence on the non-payment of premiums, Mr. Justice Buckley held that the action should be dismissed as premature.

That decision is in accordance with English practice, which will not entertain an action of declarator of a right not immediately enforceable. There might have been a doubt as to whether the same result would have followed in Scotland, where such an action is well recognised. That doubt has now been set at resi, and it may be taken as settled that neither in Scotland nor in England will tho Court determine the rights of parties in a life policy during the subsistence of the policy, and that the insurer is not bound to indicate any opinion or make any admission as to the title to a life policy until the policy becomes a claim.

$$
\text { I am, etc., }
$$

JOHN L. WARK.

Edin burah, 25th November 1907. 